\title{
Prefixal Innovations as a Mean of Psychological Impact on Consciousness Ofrecipient
}

\section{Префіксальні інновації як засіб психологічного впливу на свідомість реципієнтів}

\author{
Nataliia Kostusiak \\ Dr. of Philology, \\ Professor \\ Oleksandr Mezhov \\ Dr. of Philology, \\ Professor
Lesya Ukrainka Eastern European
National University
30-A, Vynnychenko Str.,
Lutsk, Volyn Reg.,
Ukraine, 43000

\author{
Наталія Костусяк \\ доктор філологічних наук, \\ професор
}

E-mail: nat kostusyak@ukr.net orcid.org/0000-0002-9795-6038

\author{
Олександр Межов \\ доктор філологічних наук, \\ професор
}

E-mail: mezhov@ukr.net orcid.org/0000-0002-5299-417X

Східноєвропейський національний університет імені Лесі Українки

$\triangle$ вул. Винниченка, 30-А, м. Луцьк, Волинська обл., Україна, 43000

Original manuscript received March 30, 2018

Revised manuscript accepted October 03, 2018

\section{ABSTRACT}

The article characterizes structural and derivation features of innovations, which have enriched language system during the beg inning of the XXI century and are presented in Ukrainian media text. It is emphasized on the importance of interaction between external factors and language dynamic, the advantage of studying of prefixal innovations, taking into account the text environment, functional-stylistic, and psycholinguistic specifications was grounded. It was 
mentioned, that most of the innovations have negative emotional-expressive evaluation. They include derivatives with prefixal morphemes псевдо-, квазі-, лже-, it was indicated the part-language accessory of these lexemes, their thematic grouping was proposed. It was found out the using conditions and manipulating potential of language units with prefix недо-. It was also analyzed emotional-expressive coloration and pragmatic direction of innovations with formant пост-. Used in the press, prefixal morphemes aнmи-, гіпер- are consider edas components with double function, since they can mark both negative and positive features due to the con text. Functional-psycholinguistic analysis has caused the differentiation of small group of lexemes with prefixes de-, контр-, which also have evaluating connotations, however un like mention edabove un its, are greatly specialized on explication of positive emotional-evaluating influence on the recipient. Different writing of analyzed innovations has caused the abusing of problem of their standardized forming. In that case a specific dichotomy appears: from one side used in publicism words of mentioned sample shall comply with current norms of "Ukrainian orthography", and from another - lexemes, formed with some orthographic faults, partly exacerbate the psychological impact on the recipient.

It was madea conclusion, that in modern Ukrainian media-publicism, derivates, created with the help of prefixes, form one of the biggest group of secondary nominations, which, helping to reveal the main idea of the report, in the same time give it the emotional-expressive evaluation.

Key words: word-building, morpheme, prefix, stylistic role, vocabulary of positive and negative evaluations.

\section{Вступ}

Дериваційні ознаки слів, їхні структурні особливості, семантичні, морфологічні й стилістичні параметри, безперечно, належить до тих об'єктів, які неодноразово досліджували в лінгвістиці. Значному увиразненню специфіки похідних лексем посприяло вивчення їх 3 позицій пріоритетного нині функційного напряму, що дав змогу схарактеризувати вторинні номінації відповідно до їхнього вияву в комунікативному просторі. Ще однією позитивною рисою студій останнього часу $\epsilon$ зорієнтованість на новітню джерельну базу, дібрану передусім із сучасного медіатексту. Адже саме преса найбільшою мірою віддзеркалює еволюційнотрансформаційні зміни в житті суспільства, зокрема в політичній, економічній, соціально-культурній та інших сферах, створюючи мовні знаки задля якнайточнішої експлікації певних предметів, 
подій, явищ, тобто всього, що зараховують до позамовних чинників, які впливають на формування лексичного складу мови. Керуючись тим, що будь-який лінгвістичний феномен можна описати в аспекті мовної і мовленнєвої парадигми, схиляємося до необхідності поєднання цих двох принципів, з-поміж яких пріоритетності надаємо значно ефективнішій комунікативній моделі аналізу. Указаний спектр опрацювання великою мірою увиразнить зорієнтованість на новітній медійний дискурс як специфічне явище, що грунтується насамперед на мовних і комунікативно-прагматичних параметрах iз нашаруванням емоційно-експресивних відтінків та інших стилістичних характеристик висловлення. 3 огляду на це мету статті вбачаємо в дослідженні структурно-дериваційних ознак неолексем як специфічного засобу психологічного впливу на свідомість адресата в українській публіцистичній комунікації.

\section{Методи та методики дослідження}

Для досягнення сформульованої мети використано такі методи студіювання: описовий із властивими йому прийомами зовнішньої та внутрішньої інтерпретації, що дав змогу розкрити структурнозмістові ознаки новотворів початку XXI ст., інвентаризувати й систематизувати морфеми як один із засобів оформлення інтенцій мовця; методу комплексного аналізу, що посприяв розглядові аналізованих компонентів на тлі лексико-семантичного, морфемного, словотвірного та стилістичного рівнів мови й акцентуванні на емоційному та експресивно оцінному значенні інновацій; методу контекстуально-семантичного аналізу, який уможливив вивчення неолексем в аспекті текстового оточення та 3 більшою вірогідністю окреслити їхню психолінгвістичну специфіку; методики компонентного аналізу для дослідження семних характеристик розгляданих мовних одиниць.

\section{Результати та дискусії}

Сучасні еволюційні зміни, що відбуваються в українській мовній системі й засвідчені головно в мас-медійному просторі, стали об'єктом студіювання представників багатьох лінгвістичних напрямів й віддзеркалені в різножанрових наукових працях монографіях, словниках, статтях, доповідях тощо. Грунтовний опис лексичних інновацій та переконливу аргументацію 
їхньої спеціалізації у вітчизняній лінгвістиці запропонували К.Г. Городенська (2015), С.А. Карпіловська (2011), А.М. Нелюба, Є.О. Редько (2014), М.І. Навальна (2017), О.Л. Кирилюк (2014; 2015) та ін. Психолінгвістичний аналіз мовних одиниць відбитий у низці досліджень українських та зарубіжних науковців (Інформаційно-психологічне протиборство (еволюція та сучасність), 2013; Giles, 2003; Novick, Kim, Trueswell, 2003; Tausczik, Pennebaker, 2010). Поза всяким сумнівом, усі ці та багато інших праць дають чіткі уявлення про різноманітні, частково й структурно-дериваційні, ознаки новотворів, хоч i не вичерпують обсягу порушеної проблеми. Усвідомлюючи й позитивно оцінюючи розмаїтий за аспектами дослідження новітній мовознавчий доробок, уважаємо за потрібне наголосити на важливості аналізу представлених у медіа текстах неолексемах. Вагомість і необхідність їхнього студіювання пов'язуємо насамперед із тим, що процес мовної динаміки безперервний, продукування нових лексем відбувається постійно, тому порушена тема впродовж тривалого часу, а особливо останніх років не втрачає актуальності.

Крім того, варто вказати ще на кілька важливих аргументів, які дають підстави вдатися до опису вторинних номінацій. По-перше, не викликає сумніву той факт, що суто дериваційний аналіз новотворів, які поповнили мовну систему протягом початку XXI століття, повною мірою не забезпечує об'єктивного й різноаспектного дослідження порушеної проблеми. Значно поглиблює іiї студіювання інновацій $з$ огляду на текстове оточення та функційно-стилістичні параметри. По-друге, пріоритетність визначають також принципи, якими керуються автори газетно-журнальних матеріалів. До низки найважливіших параметрів публіцистики поряд з інформативністю, переконливістю, доступністю та простотою форми викладу, безперечно, належить зорієнтованість на соціальну оцінність, експресивність, емоційність, образність та ін. Пропонуючи певну інформацію й почасти продукуючи нові номінації, автор, 3 одного боку, вдається до економії мовних засобів, а 3 іншого - зважає на особливості іiі сприйняття, розуміння й наслідки впливу на реципієнта. Володіючи основами риторичної компетентності, вдало послуговуючись лінгвопрагматичними алгоритмами, мовець прагне реалізувати певні комунікативні стратегії й дібрати для цього найяскравіші вербальні засоби їхньої реалізації. Подані 
аргументи вияскравлюють необхідність і важливість дослідження новотворів із позицій психолінгвістики. Як відомо, виникнення тих чи тих лексичних одиниць значною мірою спроектоване насамперед суспільно-політичними та економічними процесами в державі. Тому вплив зовнішніх чинників на мовну динаміку безсумнівний. Слушні думки з цього приводу висловлює С.А. Карпіловська: «...ті, хто в своїх дослідженнях спирається на аналіз структури мови, чинники й наслідки мовних змін шукають у характері відношень між мовними одиницями, між системою мови й суспільною практикою, між системою мови й мовною свідомістю іiі носіїв» (Карпіловська, 2011: 4).

Українську лексичну систему як своєрідне й різнопланове лінгвістичне явище, регульоване стратегіями й тактиками учасників комунікативного процесу та прямо чи опосередковано пов'язане 3 вираження різноманітних позамовних ситуацій, розглядають у проекції на різні критерії й ознаки, серед яких чільне місце посідає оцінка. Емоційно-оцінний вияв мовних одиниць прийнято аналізувати насамперед відповідно до опозиції позитивного / негативного судження про предмети, явища, події тощо, на позначення яких використано лексеми зазначеного зразка. 3 огляду на соціальноекономічні трансформації, суспільні процеси, що відбуваються в Україні протягом останніх років, український мас-медійний простір, крім слів із позитивним значенням, поповнила значна кількість дериватів із виразною негативною конотацією. Зазначену тенденцію простежує й M.I. Навальна: «На початку XXI століття в мові українських друкованих засобів масової інформації актуалізувалася лексика $з$ негативно оцінним значенням, що спричинене низкою позамовних чинників: економічною та політичною кризами, військовими діями на сході України, криміналізацією суспільства, соціальними проблемами та ін.» (Навальна, 2017: 94). Порушуючи проблему мовної динаміки та акцентуючи на лексемах із негативною семантикою, О.Л. Кирилюк постулює: «Людські страхи, комплекси, сподівання, розчарування - це ті головні психологічні особливості, що формують конотативний аспект появи нових слів або слів 3 новим значення, які в подальшому й стають зброєю в суспільнополітичному протистоянні» (Кирилюк, 2015: 53). Одним 3 активно застосовуваних аспектів аналізу мовних одиниць розгляданого зразка $є$ дослідження їх крізь призму маніпулятивних стратегій. 
Теорія мовних маніпуляцій не нова в сучасній лінгвістичній парадигмі. Нею керується зокрема О.Л. Кирилюк, акцентуючи на важливості психологічних чинників та мотиваційних ознак у творенні неологізмів й оказіональної лексики (Кирилюк, 2014: 315). Підсвідомий маніпулятивний вплив на адресата комунікативного процесу вбачаємо завдяки використанню в пресі значної кількості вторинних номінацій, утворених префіксальним способом. Чільне місце в системі витворених комунікативних моделей посідають деривати з префіксальними морфемами псевдо-, квазі-, лже-, які увиразнюють семантику несправжності, ірреальності, удаваності явищ чи подій суспільно-політичної та інших сфер, що негативно впливає на свідомість реципієнтів, створює враження оманливості, неправдивості багатьох реалій сучасного світу.

Мовні одиниці 3 таким модально-оцінним значенням інформують про шахраїв, різні негативні події, факти в житті суспільства, зокрема:

1) політиці: Президент Петро Порошенко прокоментував бажання псевдовлади на Донбасі провести «вибори»на окупованих територіях («Газета по-українськи», 24.09.2015); Лжеедептат із бюро добрих послуг («Голос України», 04.03.2004);

2) фінансово-економічній сфері: $У$ такому випадку, італійсько-російська фінансова група стане третьою в Украӥні за реальною фінансовою потужністю. Оскільки їх управління швидме за все буде координуватися, то мова йде про квазіоб'єднання двох банків («Львівська газета», 08.08.2015);

3) виборчих процесах чи інших формах безпосереднього волевиявлення громадян: Однак, за словами Ходорковського, призначені на березень 2018 року президентські вибори будуть «псевдовиборами», навіть якщуо на них допустять Навального $і$ Собчак, адже зміна влади на них є неможливою («Газета по-українськи», 09.12.2017); Визнавщи результати псевдоголосування, Росія зажене себе у ще більшу ізоляцію («Голос України», 05.11.2014); Організатора псевдореферендуму засудили до двох років колонії («Голос України», 10.08.2016);

4) соціальній сфері: Псевдопереселенці оббирали державу за допомогою селищної влади («Голос України», 09.04.2016); Чорнобильиі - проти лжсеінвалідів («Голос України», 28.01.2015); Виявлено люсечорнобильців («Голос України», 06.04.2012); 
5) науці: Наукова корупція як породження плагіату та недоброчесності псевдовчених («Голос України», 11.11.2016); ...nсевдопрофесора позбавили волі («Голос України», 18.02.2014); Покровитель псевдопрофесора віддав депутатський мандат («Голос України», 14.01.2012);

6) правовому полі: Псевдоправоохоронця оголошено у розшук («Голос України», 12.07.2017); П'яний псевдопрокурор влаштував стрілянину по ліхтарях («Вечірній Київ», 20.12.2015);

7) аграрній галузі: ..відтак, це свідчить про те, щзо псевдоаграрій вирішив скористатись пільговою процедурою, аби одержати землю поза аукиіоном (режим доступу: khm.depo.ua, 19.07.2017); ...ситуацію погіршуе той факт, щзо російську сторону в конфлікті підтримують украӥнські псевдоаграрії... (режим доступу: daily.rbc.ua, 09.09.2016);

8) військовій сфері: Міноборони показало псевдополковника, котрий збирав на АТО («Кореспондент», 13.09.2016); В кіниі запису псевдо-азовці спалюють прапор Нідерландів («Кореспондент», 19.01.2016). Подекуди з'являються й несправжні, удавані учасники ATO, які, використовуючи відповідний статус, збирають гроші або жебракують: Псевдо АТОшник збирає гроші на метро Льва Толстого в Києві («Вечірній Київ» 19.02.2016); Журналісти викрили псевдоАТОшника-жебрака («Кореспондент», 19.08.2016). Ілюструючи новотвори цієї підгрупи, принагідно закцентуємо на проблемі унормування виділених лексем. Як засвідчують подані приклади, журналісти практикують писати компонент nсевдоразом, через дефіс і навіть окремо. Водночас відповідно до чинного правопису цю морфему треба писати разом, тому орфографічно правильним $\epsilon$ написання псевдоазовці. Викликає певні міркування й подана в ЗМІ мовна одиниця псевдоАТОшник-жебрак. Із приводу правильності утворення однослівної назви учасника АТО слушні міркування висловила К.Г. Городенська: «Назва атовещьь відповідає українському зразкові відабревіатурного творення, оскільки в ній суфікс -ець приєднаний до твірної основи $A T O$ за допомогою структурної прокладки -ов-, що усуває збіг голосник $\boldsymbol{o}$ та $\boldsymbol{e}$ на словотвірному стикові, пор. такі самі: НАТО - натовець, сільпо сільповець, УНСО - унсовець. Отже, українською мовою учасника АTO правильно називати атовецьь» (Городенська, 2015: 127). Керуючись науково обгрунтованим коментарем дослідниці, 
зазначимо, що на позначення несправжнього учасника АТО журналіст мав би використати лексему псевдоатовець-жебрак.

Усі проаналізовані вище неолексеми 3 префіксоїдами псевдо-, квазі-, лже- належать до іменників, 3-поміж яких домінанту становлять субстантиви 3 початковим компонентом псевдо-. Акцентуючи на дериваційні параметри новотворів, вважаємо за потрібне звернути увагу на твірну базу, у ролі якої засвідчені переважно загальні назви, рідше - власні (прізвища людей, назви партій тощо), пор.: Судитимуть псевдолюстраторів («Голос України», 25.02.2016); Розшукують псевдоволонтерів («Голос України», 23.09.2015); «Лякалка» від квазіреспубліки («Голос України, 15.09.2017); Найсумніше, щзо полотно для чергової картини люсеінформаторів ми створили самі («Львівська газета», 25.04.2015); Лосемінера шукають («Голос України 09.10.2012) i ...формування фальшивих списків кандидатів в депутати від лжеБатьківщини («Газета по-українськи», 12.08.2010); Люже-Ющенко знову пише вибориям («Голос України», 09.04.2003).

Як засвідчує корпус дослідницького матеріалу, продукування лексем за допомогою морфем псевдо-, квазі-, лже-, крім іменників, пов'язане також 3 іншими частиномовними класами, переважно 3 прикметниками. У такому разі арсенал зазначених дериваційних формантів очолює префіксоїд квазі-. Наприклад: Самоусунення Києва від вирімення проблем на Донбасі розв'язуе руки сепаратистам, які за підтримки Кремля формують мілітаризовану зону із квазідержсавними інституціями («Львівська газета», 04.12.2014); ...фракиії Народного Фронту та Блоку Петра Порошенка змушені були <-.> звернутися по підтримку до двох квазіолігархічних парламентських груп - «Відродження» та «Волі Народу» («Львівська газета», 08.12.2017); Тому він [Путін. - Н. К., О. М.] залишає там свої війська і своїх представників, але ичі люди демонструють квазімирну риторику для того, щзоб показати, щзо нібито вони готові до миру, а Україна - ні («Львівська газета», 11.09.2015).

На нашу думку, деякої психолінгвістичної інтерпретації потребують непослідовно оформлені загальні назви 3 першою частиною псевдо-, квазі-, лже-. Згідно з правилами «Українського правопису», зокрема $§ 25$, п. 4, а) (Український правопис, 2012: 37), такі лексеми треба писати разом: псевдопосвідчення, 
квазіавтономія, квазіподатковий, квазівигнаниі, люеінформатор, лжемінерство тощо. Водночас у пресі трапляються форми на зразок псевдо-посвідчення, квазі-державний, квазі-податковий, люемінерство, наприклад: В Одесі водій із псевдо-посвідченням СБУ збив мотоиикл («Кореспондент», 24.08.2017); ...в Росії більше не існує Держплану, панівні позиції в ї̈ економіці займають квазідержжавні компанії («Кореспондент», 18.01.2015); Ключовою темою зустрічі стало загострення безпекової ситуачї на сході України та провокативні кроки РФ та підтримуваних нею бойовиків, передусім $<\cdots>$ запровадження квазі-податкової та банківської систем тощо («День», 31.03.2017); Столицю накрила хвиля люее-мінерства («Вечірній Київ», 03.12.2015). Припускаємо, що написання їх через дефіс пов'язане радше не 3 прогалинами журналістів в орфографії, a, ймовірніше, 3 метою концентрації уваги на новотворах, які часто надають висловленню пейоративно маркованого емоційного забарвлення. В арсенал журналістів подекуди потрапляють аналітично представлені номінації аналізованого зразка: ...nроте повідомити про зміст розмови Шеремет не встиг. Він відвідував так званий офісний центр «Москва-Сіті», де всі намі квазі вигнанці, яких ми обов'язково дістанемо $i$ засудимо («Газета по-українськи», 26.07.2016). Преференцію такого написання, крім прагматичної орієнтації на читача, вбачаємо ще й в акценті на масштабності, надзвичайності, значному вияві опредметненої динамічної ознаки, яка перебуває за межами якогось стандарту, задля употужнення психологічного впливу на реципієнта.

Викликають зацікавлення також засвідчені в пресі субстантиви на кшталт лже-Батьківщина, лже-Ющенко. Припускаємо, що форми вказаного зразка з'явилися під впливом написаних через дефіс власних назв із першим компонентом пів-, напів- відповідно до § 26, п. 1, д): пів-Свропи, пів-Києва (Український правопис, 2012: 39). Сподіваємося, що орфографічне оформлення розгляданих неолексем буде відбите в наступному виданні «Українського правопису».

Отже, уживані в мас-медійній комунікації іменники та прикметники 3 першими компонентами псевдо- квазі-, лжереалізують чітку прагматичну семантику. Автори, продукуючи тексти з такими мовними одиницями, мають на меті вплинути на формування суспільної думки, намагаються об'єднати навколо порушеної проблеми якомога більше читачів. Схарактеризована 
комунікативна модель подання інформації сприятиме усвідомленню реципієнтом того, що сьогодні суспільство живе в якомусь не реальному, а сюрреалістичному світі, де можуть бути несправжні політики, військові, науковці, аграрії, волонтери, неправдива влада, виборчі процеси тощо поряд із значною кількістю соціально незахищених людей. А це свідчення хаосу, анархії, свавілля, домінування неправди над правдою, безвиході, безперспективності, невизначеності майбутнього, що психологічно пригнічує насамперед середній клас і найбідніші верстви населення.

В українській публіцистичній комунікації журналісти усвідомлено використовують маніпуляційний потенціал мовних одиниць із префіксом недо-, за яким традиційно закріплена семантика недовершеності, неповноти, нереалізованості. Функціонування неолексем із цим формантом зумовлене прагненням створити яскраву номінацію, зактуалізувавши у свідомості реципієнта близькі за дериваційними ознаками лексеми, що мають негативне значення. Наприклад: Причому йдеться не про одну поразку, а про иілу низку падінь з владних височин, щчо за умов розвиненого демократичного ладу може бути ще більи небезпечним, аніж за умов вітчизняної недодемократії («Українська правда», 20.12.2010). Своєрідну мовленнєву філігранність демонструють автори, послуговуючись одночасно кількома неолексемами 3 префіксом недо-, який посилює негативні враження, употужнює ефект несправжності, недовершеності: Порушено питання про деяких російських недоолігархів, як я їх називаю, які активно спілкуються з українською політичною елітою. Назвав би їх недополітичною недоелітою, яка хоче дестабілізувати ситуацію («Газета по-українськи», 26.01.2016).

Кількісно невелику групу новотворів структурують мовні одиниці з формантом nост-. Попри позитивне ставлення до подій Майдану, а отже й позитивні асоціації, які викликає ця лексема, у пресі негативного відтінку набуває похідне слово постмайданний, використовуване у зв'язку з висвітленням дій теперішньої влади, що не виправдала вповні сподівань українців: Ющенко назвав глобальну помилку постмайданної влади («Газета по-українськи», 30.11.2017); Постмайданна влада досі підіграє олігархам? Не настільки, щзоб державою керували вони. Олігархи вже не мають вирімального впливу... («Газета по-українськи», 11.08.2017). 
Крім префіксальних морфем, які употужнюють головну інтенцію висловлення, піднімають градус напруження, особливо коли йдеться про порушення моральних цінностей (справедливості, чесності, честі, гідності та ін.), залишаючи у свідомості реципієнта негативні відчуття, у медіа текстах засвідчені префіксальні форми 3 подвійною функцією. Вони здатні викликати не тільки негативну, а й позитивну реакцію адресата. 3'ясувати психолінгвістичну основу таких неолексем дає змогу контекст.

Розкрити певну ідею, водночас впливаючи на когнітивну й емоційну сфери особистості, допомагають новотвори 3 префіксом анти-. У лексикографічній праці «Лексико-словотвірні інновації. 2012-2013: Словник» А.М. Нелюба й Є.О. Редько подають низку іменників із цим афіксом, тлумачачи їх як протилежні поняття до слів без вказаного форманта або як маркери особи-противника когось. Прикметники 3 префіксом анти-, на думку науковців, зазвичай експлікують ознаку того, хто/що проти чогось, вираженого словом без анти- (Нелюба, Редько, 2014: 11-16). Докладний аналіз джерельної бази дав змогу чіткіше простежити градаційну опозицію негатив/позитив як емоційну реакцію аудиторії. Останнім часом через воєнні дії, розв'язані Росією, з'явилося чимало лексем, утворених від прізвища Президента Російської Федерації. Негативні дії Путіна, його небезпеку для цивілізації дедалі більше усвідомлюють не тільки українці, але й самі росіяни, європейці. Наприклад: Російські антипутінці винахідливо затролили телепропагандиста Владіміра Соловйова («Online Експрес», 25.07.2017); У Римі пройшла чергова антипутінська акиія протесту, ініційована Оргкомітетом Свромайдану Рима («Львівська газета», 14.07.2014). Подекуди журналісти вдаються до своєрідного маскування маніпуляційної мети свого повідомлення. Наслідком камуфляжування такого зразка можна вважати лексеми 3 префіксом анти-, що корелюють iз прізвищем російського Президента, коли йдеться не суто про цю людину, а про Росію загалом. У такому разі реципієнт повинен дешифрувати подану інформацію, вибудовуючи певний ланцюг аргументів, що ще більшою мірою посилює негативність поданої номінації. Наприклад: Головний тренер «Динамо» зробив антипутінську заяву, $\langle\cdots\rangle$ сказав про своє ставлення до «Газпрому» та Росії («Online Експрес», 09.12.2015). Аналогічне функційне призначення й опертя на асоціативні уявлення вбачаємо 
у використанні лексеми метонімічного різновиду антитабачний: Антитабачний настрій. Масовий мітинг за відставку Міністра освіти $і$ науки України Дмитра Табачника у Львові («Вголос», 20.04.2010). Зрозуміло, що приписувані Д. Табачнику русифікація, корупція, знищення системи об'єктивного оцінювання знань та ін. не стосуються дій суто цієї людини, а колективу працівників усього Міністерства. Проте завдяки слову антитабачний автор дає змогу читачам зрозуміти, що відповідальність за уникнення негараздів в освіті та науці покладені особисто на керівника, тому й люди намагаються його усунути 3 цієї посади.

Спротив у суспільстві викликає й продовження економічних, торговельних відносин із Росією, антисоціальна, корупційна діяльність олігархічної влади, у зв'язку з чим з'являються антирейтинги політиків. Наприклад: Фінансування науки поставило антирекорд («Голос України», 16.06.2016); У податковій сфері суперечливі рухи. Там зробили більше антиреформ («Газета по-українськи», 03.06.2015); У бюджеті на 2015 рік насправді інічійовано антиреформи («Газета по-українськи», 03.03.2015); Україна очолила антирейтинг з корупиї через бездіяльність антикорупиійних органів... («Газета по-українськи», 12.12.2017); Не менш вражає $i$ антирейтинг українських політиків... («Газета по-українськи», 20.12.2017).

Часто контекстуальне оточення словотвірної моделі 3 префіксом анти- створює в пресі й позитивні конотації, вказуючи на тенденції протидії негативним явищам, експлікуючи позитивні зрушення в суспільстві, потреби кардинальних змін. Своєрідної патетики набувають контексти, де йдеться про прозріння соціуму у ставленні до політиків, влади, усвідомлення й об'єктивного оцінювання ii негативних, неефективних реформ. Це вселяє в людей надію на краще майбуття, додає оптимістичного настрою, створює психологічний ефект душевної рівноваги. Наприклад: Антикорупціонери не дали вкрасти 2 млрд грн. («Українська правда», 19.02.2018); Інвестиції - інструмент антикорупції («Голос України», 13.10.2017).

Переважно позитивний психологічний клімат у суспільстві, яке сповідує європейські цінності, створює відмова від старого, негативного, віджитого шляхом активізації процесів декомунізації, дебільшовизації, дефашизації. Емоційне піднесення викликають у 
реципієнтів і позитивні процеси в економічній сфері, пов'язані 3 демонополізацією, деолігархізацією, деофшоризацією, детінізацією. Саме префікс де- надає лексемам значення опредметненої дії (процесу), протилежної до негативної. Наприклад: Відбувається те, щзо мало б статися щзе на початку нашої незалежності: декомунізація, дебільшовизація, якщо хочете - дефашизація краӥни («Львівська газета», 27.02.2014); Сергій Лещзенко може увійти до тимчасової слідчої комісії з деофшоризації («Газета по-українськи», 20.05.2016); Ti, хто звик грабувати країну, опираються деолігархізації («Голос України», 20.08.2015).

Схоже психоемоційне навантаження мають мовні моделі 3 префіксоїдом контр-, що позначають переважно позитивні події, явища, які відбуваються впротивагу іншим, негативним і $€$ відповіддю на них: «Ця пропаганда вимагає намої реакції. Однак нашою відповіддю не може бути контрпропаганда, ие мають бути об'єктивні інформаційні програми російською мовою», наголосив під час конферениії глава МЗС Польщзі Гжегож Схетина («Львівська газета», 11.09.2015).

Увиразнити надзвичайність, масштабність подій, явищ i водночас реалізувати позитивний лінгвопсихологічний вплив на реципієнтів покликані новотвори 3 префіксоїдом гіпер-: $A$ цей період потрібно пережсти - але час зараз не такий як раніше він просто гіперінформаційний... («Українська правда», 26.04.2010). Хоч подекуди напрям емоційної трансформації змінюється. Наприклад, роль ефективного засобу формування негативної оцінки в реципієнта виконує дериват гіперінфляція в реченні Вона періодично викидала на фінансовий ринок величезні маси емісійних купонів, чим знецінювала їх; гіперінфляція в Украӥні сягнула одного з найвищих у ХХ столітті показників («День», 18.07.2014).

\section{Висновки}

У новітній українській медіапубліцистиці утворені префіксальним способом деривати формують одну 3 найпоширенішим груп вторинних номінацій, які дають змогу розкрити головну ідею повідомлюваного, створити ефективну комунікативну модель, здатну викликати реакцію аудиторії, i водночас надають текстові емоційно-експресивного забарвлення. Удокладнений функційно-психолінгвістичний аналіз розгляданих 
одиниць з огляду на вираження ними оцінної конотації передбачає розмежування формантів, які в сучасній пресі зазвичай виконують роль маркерів негативного емоційно-оцінного впливу на адресата (псевдо-, квазі-, лже-, недо-, пост-); морфем, що увиразнюють i негативну, i позитивну ознаки відповідно до контексту (анmu-, zinep-), а також невелику групу лексем із префіксами де-, контр-, значною мірою спеціалізованих на прогнозуванні позитивних емоцій реципієнта. Перспективу дослідження вбачаємо в студіюванні 3 позицій психолінгвістики суфіксальних неолексем, використовуваних у новітньому мас-медійному дискурсі.

\section{Література}

Городенська К.Г. Атошник чи атовець? Культура слова. 2015. Вип. 83. С. 127. Інформаційно-психологічне протиборство (еволюція та сучасність) : монографія / Жарков Я.М. та ін. Київ : ПАТ «Віпол», 2013. 248 с.

Карпіловська Є.А. Зміни в структурі сучасної української мови та можливості їх моделювання. Украӥнська мова. 2011. № 2. С. 3-18.

Кирилюк О.Л. Мовні одиниці як зброя в суспільно-політичному протистоянні. Актуальні проблеми прикладної. Одеса : Букаєв Вадим Вікторович, 2014. Вип. 1. С. 314-319.

Кирилюк О.Л. «Вогнехреще» або неологізми як відображення військового протистояння. Наукові записки. Серія: Філологічні науки. Кіровоград: Кіровоградський держ. пед. ун-т ім. Володимира Винниченка, 2015. Вип. 137. С. 52-57.

Навальна М.I. Пейоративи в мові української періодики. Психолінгвістика. Психолингвистика. Psycholinguistics. 2017. Вип. 22 (2). С. 85-97.

Нелюба А.М., Редько С.О. Лексико-словотвірні інновації. 2012-2013: Словник / заг. ред. А.М. Нелюби. Харків : Харківське історико-філологічне товариство, 2014. 172 c.

Український правопис / НАН України, Ін-т мовознавства ім. О.О. Потебні; Інститут української мови. Київ : Наукова думка, 2012. 288 с.

Giles, D. (2003). Media Psychology. Mahwah, New Jersey, London : Lawrence Erlbaum Associates, Publishers.

Novick Ja.M., Kim A., \& Trueswell J.C. (2003). Studying the Grammatical Aspects of Word Recognition: Lexical Priming, Parsing, and Syntactic Ambiguity Resolution. Journal of Psycholinguistic Research, (32, 1), 57-75.

Tausczik Y., \& Pennebaker J.W. (2010). The Psychological Meaning of Words: LIWC and Computerized Text Analysis Methods. Journal of Language and Social Psychology, 29(1), 24-54. doi.org/10.1177/0261927X09351676.

\section{References}

Horodenska, K.H. (2015). Atoshnyk chy atovets? [Atoshnik or Atovets?]. Kultura slova-Culture of the word, 83, 127 [in Ukrainian].

Zharkov, Ya.M., $\quad$ Petryk, V.M., $\quad$ Prysiazhniuk, M.M., Skulysh, Ye.D., \& Kompantseva, L.F. et al. (2013). Informatsiino-psykholohichne protyborstvo 
(evolutsiia ta suchasnist) [Information-psychological confrontation (evolution and modernity). Kyiv : PAT «Vipol» [in Ukrainian].

Karpilovska, Ye.A. (2011.) Zminy v strukturi suchasnoyi ukrayinskoyi movy ta mozhlyvosti yikh modelyuvannya [Changes in the structure of modern Ukrainian language and possibilities of their modeling]. Ukrayinska mova - Ukrainian Language, 2, 3-18 [in Ukrainian].

Kyrylyuk, O.L. (2014). Movni odynytsi yak zbroya v suspilno-politychnomu protystoyanni [Linguistic units as a weapons in a socio-political confrontation]. Aktualni problemy prykladnoyi linhvistyky - Actual problems of applied linguistics. Odesa : Bukayev Vadym Viktorovych, 1, 314-319 [in Ukrainian].

Kyrylyuk, O.L. (2015). «Vohnekhreshche» abo neolohizmy yak vidobrazhennya viyskovoho protystoyannya [«Fire-chest» or neologisms as a reflection of a military confrontation]. Naukovi zapysky - Scientific notes. Kirovohrad: Kirovohradskyy derzh. ped. un-t im. Volodymyra Vynnychenka, 137, 52-57 [in Ukrainian].

Navalna, M.I. (2017). Peyoratyvy v movi ukrayinskoyi periodyky [Pejoratives in language of Ukrainian periodicals]. Psykholinhvistyka - Psycholinguistics, 22(2), 85-97 [in Ukrainian].

Nelyuba, A.M., \& Redko, Ye.O. (2014). Leksyko-slovotvirni innovatsiyi. 2012-2013: Slovnyk [Lexico-word-building innovations. 2012-2013: Dictionary]. Kharkiv : Kharkivske istoryko-filolohichne tovarystvo [in Ukrainian].

Ukrayinskyy pravopys [Ukrainian orphography] (2012). Kyiv : Naukova dumka [in Ukrainian].

Giles, D. (2003). Media Psychology. Mahwah, New Jersey, London : Lawrence Erlbaum Associates, Publishers.

Novick Ja.M., Kim A., \& Trueswell J.C. (2003). Studying the Grammatical Aspects of Word Recognition: Lexical Priming, Parsing, and Syntactic Ambiguity Resolution. Journal of Psycholinguistic Research, (32, 1), 57-75.

Tausczik Y., \& Pennebaker J.W. (2010). The Psychological Meaning of Words: LIWC and Computerized Text Analysis Methods. Journal of Language and Social Psychology, 29(1), 24-54. doi.org/10.1177/0261927X09351676.

\section{АНОТАЦІЯ}

У статті схарактеризовано структурно-дериваційні ознаки новотворів, які поповнили мовну систему протягом початку XXI століття й представлені в українських медіатекстах. Наголошено на важливості взаємодії зовнішніх чинників та мовної динаміки, обгрунтовано перевагу дослідження префіксальних інновацій з огляду на текстове оточення, функційно-стилістичні та психолінгвістичні параметри. Зазначено, що більща частина новотворів має негативне емоційноекспресивне забарвлення. До них зараховано деривати з префіксальними морфемами псевдо-, квазі-, лже-, вказано на частиномовну належність цих лексем, запропоновано їхнє тематичне групування. З'ясовано умови використання та маніпуляційний потенціал мовних одиниць із префріксом недо-. Проаналізовано емоційно-експресивне забарвлення 
та прагматичне спрямування новотворів із формантом пост-. Засвідчені в пресі префіксальні морфеми анти-, гіпер- розглянуто як компоненти з подвійною функцією, оскільки вони здатні маркувати і негативні, і позитивні ознаки відповідно до контексту. Функційнопсихолінгвістичний аналіз зумовив вирізнення невеликої групи лексем із предріксами де-, контр-, що також мають оцінні конотації, проте на відміну від поданих вище одиниць значною мірою спеціалізовані на експлікації позитивного емоційно-оцінного впливу на адресата. Різне написання розгляданих новотворів зумовило порушення проблеми їхнього унормованого оформлення. У такому разі виникає своєрідна дихотомія: з одного боку, використані в публіцистиці слова вказаного зразка мають відповідати чинним нормам "Українського правопису», а з іншого - лексеми, оформлені з певними орфографічними порушеннями, почасти употужнюють психологічний вплив на реципієнта.

Зроблено висновок, що в новітній українській медіапубліцистиці утворені префіксальним способом деривати формують одну 3 найпоширенішим груп вторинних номінацій, які, допомагаючи розкрити головну ідею повідомлюваного, водночас надають йому емочійноекспресивного забарвлення.

Ключові слова: словотвір, морфема, префікс, стилістична роль, лексика з позитивною та негативною оцінкою.

Костусяк Наталия, Межов Александр. Приставочные инновации как средство психологического воздействия на сознание реципиентов

\section{АННОТАЦИЯ}

В cmamье характеризуются структурно-деривационные признаки новообразований, представленных в украинских медиатекстах и пополнивших языковую систему в начале XXI века. Подчеркивается важность взаимодействия внешних факторов и языковой динамики, обосновывается преимущество исследования приставочных инноваций с учетом текстового окружения, функционально-стилистических и психолингвистических характеристик. Отмечается, что большая часть новообразований имеет отрицательную эмоционально-экспрессивную окраску. $К$ ним относатся дериваты с префиксальными морфемами псевдо-, квазі-, лже-. Указывается на частеречную принадлежность этих лексем, предлагается их тематическая группировка. Выяснены условия использования и манипуляционный потенциал языковых единиц с приставкой недо-. Анализируется эмоционально-экспрессивная окраска и прагматическое направление новообразований с формант пост-. Функционирующие в прессе приставочные морфемы анти-, гіперрассматриваются как компоненты с двойной функцией, поскольку они 
способны маркировать и отрицательные, и положительные признаки в соответствии с контекстом. Функционально-психолингвистический анализ обусловил выделение небольщой группы лексем с приставками де-, контр-, также имеющих оценочные коннотации, однако в отличие от представленных выше единии, в значительной степени специализированных на экспликации положительного эмоционально-оценочного воздействия на адресата. Разное написание рассматриваемых новообразований обусловило решение проблемы их нормированного оформления. В таком случае возникает своеобразная дихотомия: с одной стороны, использованные в публицистике слова указанного типа должны соответствовать действующим нормам "Украинского правописания", а с другой - лексемы, оформленные с определенными орфографическими нарушениями, отчасти усиливают психологчческое воздействие на реципиента.

Сделан вывод, что в современной украинской медиапублицистике образованные префиксальным способом дериваты формируют одну из наиболее распространенных групп вторичных номинаций, которые, помогая раскрыть главную идею сообщения, одновременно придают ему эмоционально-экспрессивной окраски.

Ключевые слова: словообразование, морфема, префикс, стилистическая роль, лексика с положительной и отрицательной оценкой. 